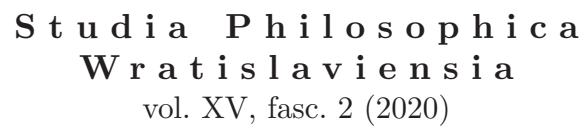

https://doi.org/10.19195/1895-8001.15.2.5

\author{
URSZULA LISOWSKA
}

ORCID: 0000-0003-2177-6732

University of Wrocław

\title{
Towards a Materialist Phenomenology of Wonder: Comments on Bendik-Keymer and Małecki
}

There is an obvious asymmetry between the three papers comprising the Wonder seminar - whereas Jeremy Bendik-Keymer's and my own contributions argue for the political and ethical relevance of wonder, Wojciech Małecki is highly critical of this claim. Moreover, given that my paper has been considerably influenced by Bendik-Keymer's work, there is indeed - as he observes in his commentary - a significant overlap between our perspectives. Hence, for the most part of what follows, I will address Małecki's criticism. In so doing, I will at times draw on Bendik-Keymer's observations. However, in the final part of the comment, I will sketch an alternative to an important element of Bendik-Keymer's proposal.

\section{The phenomenology of wonder}

The confrontation with a criticism as lucid as that by Małecki pushes one to clarify their own position. Therefore, when responding to his stimulating challenge, I will try to improve on the original formulation of my approach. For one thing, this is necessitated by the comprehensiveness of Małecki's paper-he offers an analysis of the difficulties that any proponent of wonder would be well-advised to take into account. The force of his challenge is further emphasised in the conclusion, when Małecki offsets a merely verbal solution to his charges (i.e. a simple redefinition of the disputed term: "Well, what you're talking about simply isn't what I mean by »wonder «!"). Together, the span of the critique and the precaution against its conceptual dismissal make Małecki's challenge an especially serious one. And yet, I would like to take my chances and argue that what I was describing indeed does not coincide with the object of Małecki's criticism. Moreover, given the discrepancy between the respective topics of our papers, I will leave out some 
of Małecki's critical points, addressing only those that are relevant to the phenomenon I am interested in.

It is indeed a phenomeno(n)logical question. For it is important to notice that Małecki's analysis presupposes a specific ontology of wonder-namely, he conceptualises wonder as an emotion, which, in turn, is construed as an object of natural sciences. This, however, is a stronger assumption than I would be ready to make. In the paper, I considered several possibilities of categorising wonder - as a pathos linked to the origins of philosophy (Arendt), an emotion as defined by a hybrid philosophical-scientific theory (Nussbaum) or a proto-judging operation (Bendik-Keymer). More generally, I am interested in the phenomenology of wonder, that is: in capturing the experiences referred to as "wonder". It is possible that a full account of the phenomenology of wonder will escape clear categorisation. In any case, from the perspective of this methodology, the implicit initial commitment to one way of conceptualising wonder (e.g. as an emotion - an object of natural sciences) seems - if not hasty, then - unduly limiting.

The phenomenological focus also means that I perceive the possible political relevance of wonder differently than Małecki construes it. Małecki's critical arguments concern wonder's ability "to change the world"1 in a desirable way. Indeed, its ambiguous, if not harmful, nature as an emotion could be an important obstacle to Nussbaum's liberal (but perhaps slightly social engineering-ish) vision of civic education - we should be wary of placing too much weight on such a volatile resource. Yet my interest in wonder, rather than educational and stabilising, is foundational. That is to say: I would like to not so much demonstrate wonder's role in maintaining a specific politico-ethical order as to employ this category to illuminate the basis of politics. My focus is on how the experiences captured by the term "wonder" contribute to the creation of the political sphere. Naturally, this approach does have normative implications, inasmuch as politics is a practical concept. But my appeal to wonder is not instrumental -instead, I see it as constitutive of politics, partaking in the formation, rather than mere maintenance, of this normative environment.

\section{Objection to (rather than) objectification}

The second reason why I find Małecki's criticism stimulating is that the passion of his attack on wonder compels me to somewhat qualify its defence. I only hinted at its ambivalence when discussing the paradoxical relationship between thaumadzein and doxa in Arendt's approach. I would now argue that wonder is inherently ambiguous - it is located between philosophy and politics, dzoe and bios, the sublime and the beautiful. Rather than being specifically linked to any of these categories, it potentially works as a transitional force within each of the conceptual pairs. ${ }^{2}$ This

\footnotetext{
${ }^{1}$ W.P. Małecki, "Against Wonder", Studia Philosophica Wratislaviensia 15 [2] (2020), p. 55.

${ }^{2}$ In particular, I would like to qualify the clear-cut connection between wonder and the beautiful that I defended in the paper. I now think of wonder as the potential of moving from the beautiful to
} 
potentiality defines, in turn, the relationship between wonder and judgment, the latter functioning as its actualising factor.

Let me explain this interpretation by addressing one of Małecki's specific charges. Małecki argues that, far from inspiring respect for a wonderful being's living dignity, wonder can lead to its/his/her objectification for the sake of pleasurable admiration. The wonderful entity is thus construed as an exotic exhibit, rather than being celebrated for its/his/her autonomy. Interestingly, Małecki cites Iris Marion Young at this point; her remarks on the risk of objectification referred, in turn, to Luce Irigaray's observations on wonder and sexual difference. However, after rejecting the potentially objectifying interpretation of wonder, Young juxtaposes it with "a respectful stance of wonder". ${ }^{3}$ While this move could at first be read as a mere verbal solution that Małecki rightly opposes, Young justifies it by linking wonder to the operation of judgment, understood Arendtian-wise. Working in tandem, the two result in what Young describes as "asymmetrical reciprocity". On the one hand, judgment "processes" wonder so that the admiration for the novel translates into the urge to reach out to and communicate with this strange point of view. On the other hand, "fuelled" by wonder, judgment renounces the ideal of the reversibility of positions - whatever agreement judgment can "solicit" ${ }^{4}$ it respects the ineliminable differences between diverse perspectives.

Similar intuitions are at play in Bendik-Keymer's paper, when he argues that a world common to different worlds can only emerge through disagreement (the space for which is secured by wonder). Or, to put it differently, objectivity is generated through the tensions between objections. This is very much Arendtian in spirit, given that Arendt drew radical consequences from the German concept of an object as der Gegenstand, i.e. roughly, that which stands opposite to me. ${ }^{5}$ For Arendt, objectivity emerges not only through the opposition to a single subjectivity, but also through the clash of different visions of objectivity related to various subjective positions. Whatever validly counts as an object violates me as a subject, including the objectivity relative to my subjectivity. ${ }^{6}$ Thus, on these accounts the claim that wonder leads to objectification could indeed be maintained. However, it would have an entirely different meaning than the one Małecki rightly criticises - wonder is objectifying in that it opens the space for objectivity-engendering disagreements and differences.

\section{Conclusion - an alternative to anthroponomy?}

What remains to be determined is the scope of the differences that should be covered by asymmetrical reciprocity. Whereas on the orthodox Arendtian reading

the sublime. For the attempt at "rescuing" wonder from the sublime, see: G. Lloyd, Reclaiming Wonder: After the Sublime, Edinburgh 2018.

${ }^{3}$ I.M. Young, "Asymmetrical Reciprocity: on Moral Respect, Wonder, and Enlarged Thought", [in:] Judgment, Imagination and Politics. Themes from Kant and Arendt, R. Beiner, J. Nedelsky (eds.), Lanham-Oxford 2001, p. 222.

${ }^{4}$ I. Kant, The Critique of Judgment, transl. W.S. Pluhar, Indianapolis-Cambridge 1987, § 19, p. 86.

${ }^{5}$ H. Arendt, The Human Condition, Chicago-London 1998 (1958), pp. 137-138.

${ }^{6}$ Ibid., pp. 57-58. 
the diversity of positions does not extend beyond the human world, Bendik-Keymer rightly observes that contemporary politics and ethics have to allow for more than human reality. This, he argues, can be achieved by adopting the orientation of anthroponomy - the type of accountability whereby humanity regulates itself as a whole in the conditions of our actions having unintended consequences on a planetary scale. ${ }^{7}$ Anthroponomy integrates the individual into the collective in a response to the disappearance of the clear boundaries of social processes and as such alerts us to their effects in the more than human world.

The concept of anthroponomy is testament to Bendik-Keymer's opposition to the misanthropic tendencies in environmental philosophy. Rather than proclaiming anti-humanism, he has always been dedicated to the idea of deriving the commitment to the more than human world from the very core of humanity. ${ }^{8}$ Yet, this approach still leaves room for humans being positioned as moral agents relative to non-human moral subjects. More specifically, the anthroponomic orientation may be insufficient to establish the relationship of asymmetrical reciprocity with non-human forms of life. For the question is: does the collective self-regulation of humanity respect the irreducibly different non-human points of view? Or does it entail conceptualising the latter in human terms?

To this it could be responded that there simply is no meaningful reciprocity between human beings and a large part of the non-human world. By the same token, the latter cannot be covered by asymmetrical reciprocity. Yet, this would go against Bendik-Keymer's sound emphasis on the ethical and political significance of the more than human world (and the affinity between his and Young's approaches, for which I have argued above). My response to this difficulty would be to revise the understanding of human beings as political actors so as to include the non-human aspects as their/our constitutive elements. In that case, the more than human world is not something we relate to but, rather, what we are partly made of. I am interested in revising the Arendtian model of judgment in this direction, by offering its materialist reading. This, however, is a research proposal that I can only signal at this point.

\section{References}

Arendt H., The Human Condition, Chicago-London 1998 (1958).

Bendik-Keymer J., "Autonomous Conceptions of Our Planetary Situation", Studia Philosophica Wratislaviensia 15 [2] (2020), pp. 29-44.

Bendik-Keymer J., The Ecological Life: Discovering Citizenship and a Sense of Humanity, Lanham 2006.

7 J. Bendik-Keymer, "Autonomous Conceptions of Our Planetary Situation", Studia Philosophica Wratislaviensia, 15 [2] (2020), pp. 29-44. See also: J. Bendik-Keymer, "Goodness itself Must Change'. Anthroponomy in an Age of Socially-Caused, Planetary Environmental Change", Ethics 63 Bioethics (in Central Europe) 6 [3-4] (2016), pp. 195-197, https://doi.org/10.1515/ebce-2016-0020.

${ }^{8}$ Cf. J. Bendik-Keymer, The Ecological Life: Discovering Citizenship and a Sense of Humanity, Lanham 2006. 
Bendik-Keymer J., "'Goodness itself Must Change'. Anthroponomy in an Age of Socially-Caused, Planetary Environmental Change", Ethics $\&$ Bioethics (in Central Europe) 6 [3-4] (2016), pp. 187-202, https://doi.org/10.1515/ebce-2016-0020.

Kant I., The Critique of Judgment, transl. W.S. Pluhar, Indianapolis-Cambridge 1987. Małecki W.P., "Against Wonder", Studia Philosophica Wratislaviensia 15 [2] (2020), pp. $46-57$.

Young I.M., "Asymmetrical Reciprocity: on Moral Respect, Wonder, and Enlarged Thought", [in:] Judgment, Imagination and Politics. Themes from Kant and Arendt, R. Beiner, J. Nedelsky (eds.), Lanham-Oxford 2001, pp. 205-228. 